\title{
Dangers and Treatment of Hypocrites' Rumors Thematic Analytical Study
}

Main Researcher

${ }^{1}$ University Name \& City:

* Corresponding author:

E-mail address:

\section{Zakaria ZenEldeen}

The Islamic University of Gaza

\section{https://doi.org/10.33976/IUGJIS.29.1/2021/17}

\section{Dangers and Treatment of Hypocrites' Rumors \\ Thematic Analytical Study}

\section{Abstract:}

The research sheds light on the role of hypocrites in spreading rumors in the Prophet's society. It reveals the dangers of such rumors through analyzing the Hadith narrated by Omar regarding the rumor of the Prophet, peace be upon him, divorcing his wives and the Hadith narrated by Aisha regarding the falsehood incident, where some reliable and honorable Companions (Sahaba) fell prey to the rumors spread by hypocrites. These rumors aimed at weakening the leadership. They spread so quickly appearing as an absolute truth, resulting in serious harm -including illness, insomnia and crying- to the accused. Analyzing the two Hadiths shows how to face and address rumors. Rumors can be overcome through preventing one's tongue from spreading the rumors, asking and referring to specialized people, being patient when one is falsely accused, relying on Allah until the truth is revealed and innocence is proven and forgiveness to erase any traces of these rumors.

Keywords: Rumor, Hypocrites, Dangers, Treatment, Thematic, Analytical.

\section{أخطار إشاعة المنافقين وعلاجها: دراسة موضوعية تحليلية}

يكشف هذا البحث عن دور المنافقين في بث الشائعات في المجتمع النبوي، ويوضح أخطار إشاعتهم من خلال؛ تحليل حديث عمر بن الخطاب فأه في إشاعة تطليق النبي في إشاعة الإفك والفاحشة عليها، والتي تمثلت في وقوع صحابة أجلاء ثقات في شَرك إشاعات المنافقين، واستهدافها إيذاء القيادة، وسرعة انتشارها حتى تكاد تصبح حقيقة لا تُكّذب، وإلحاق الأضرار البالغة من المرض والأرق والبكاء على المفترى عليه، كما ويبرز تحليل الحديثين سبل مواجهة الإشاعة وعلاجها والمتمثلة؛ بإمساك اللسان عن الخوض في الإشاعة، والتثبت والسؤال والرجوع لأهل التخصص، وتجمل المُفترى عليه بالصبر والتوكل على الله حتى ظهور الحقيقة وثبوت البراءة، والتخلق بالعفو لمسح آثار 


\section{Introduction}

All praise be to Allah, whom we seek for help. He whom Allah guides aright, there is none to mislead him, and he whom Allah leads astray, there is none to guide him. I bear witness that there is no god but Allah, who has no partners, and that Muhammad, peace be upon him, is His slave and Messenger.

After Allah has blessed his messenger with victory in the great Battle of Badr $^{(1)}$, the phenomenon of hypocrisy led by Abdullah bin Ubayy bin Saloul ${ }^{(2)}$ began to spread. Hypocrites are those who show faith and conceal disbelief ${ }^{(3)}$. This is why they are dangerous; they live among Muslims, speak with them, pray with them and know everything about them. They attempted to destroy the Prophet's mosque from the inside, so they allied with the disbelievers of Quraysh ${ }^{(4)}$ and the Jews of Al-Madinah ${ }^{(5)}$ in every possible way including the spread of rumors to confuse the society.

Hypocrites today may not conceal disbelief, but they share interests with the occupier and other enemies of our nation; the nation of Islam. These are now called the fifth column.

The Prophet's Sunnah has clarified the role of hypocrites in spreading rumors at different occasions. In this research, we address two incidents of utmost importance, as they both targeted the leader of the state, Prophet Mohammed, peace be upon him, and his household. The first incident is the rumor that the Prophet, peace be upon him, divorced his wives, and the second is the incident of falsehood $\left(\right.$ ifk $^{(6)}$ ) against the mother of believers, Aisha. The research relies on the analysis of the

(1) The Battle of Badr: (Also called the Great Battle of Badr) is the battle between Muslims and Arab polytheists and their allies on Ramadan, 17 ${ }^{\text {th }}$ AH. See: Bin Hisham, As-Sirah An-Nabaweya, Vol. 1/607

(2) Abdullah bin Ubayy bin Salul: Abdullah bin Abi Malek Bin Al-Hareth bin Ubaid (also called bin Salul). He was Chief of the Arab tribe "Banu Khazraj" in the pre-Islamic paganism. When the Prophet (peace be upon him) arrived at Al-Madinah, the people were about to gather pearls (of a crown) to crown him as the leader. This invoked bin Ubayy's jealousy and he became a hypocrite and even "the chief of hypocrites". Ibn Al-Jawzi, Al-Muntatham fi Tarikh AlMulouk Vol. 3/377

(3) Al-Jurjani, Vol. 1/40

(4) Quraysh: It is a tribe attributed to Kinanah bin Mudar bin Adnan, son of the Prophet Ismail bin Ibrahim (peace be upon them), as was narrated in the Hadith, "and he [Allah] chose Banu Kinanah from the children of Isma'il, and He chose the Quraysh from Banu Kinanah, and He chose Banu Hashim from Quraysh, and He chose me from Banu Hashim". It is the tribe of the Prophet (peace be upon him). Al-Qurtubi, al-Inbah 'ala Qaba'il al-Ruwah, Vol. 1/41

(5) Jews of Al-Madinah: are the Jews who had lived in Al-Madinah when the Prophet (peace be upon him) emigrated to it. All the people entered Islam except these Jews. They were called "the Jews of Al-Madinah- to differentiate them from other Jews. The Jews in Al-Madinah and Khaybar include Banu Qurayza, Banu Nadir and Banu Qaynuqa'. However, some of the people of the Tribes of the Aws and Khazraj converted to Judaism. Abu Al-Qasim Al-Suhayli, Al-Rawd al-Unuf, Vol.4/199

(1) The incident of Falsehood: the incident when the hypocrites accused the mother of Believers, Aisha, of adultery in the sixth year of Hijra. The incident occurred when the Prophet (peace be upon him) was on a campaign and was accompanied by Aisha. After their victory on that battle and on their way home, the Prophet (peace be upon him) wanted to stay the night at one house. Aisha wanted to relieve herself away from the army. When she was going back, and the army was getting ready to march, she realized she had lost her necklace. She went back to search for it. When 
two long Hadiths by Omar bin Al-Khattab and Aisha to deduce the dangers of rumors as well as the methods of their treatment.

\section{Research Importance:}

This research is important for the following reasons:

1. The research contributes to the thematic and analytical discourse with a new addition on the dangers and treatments of rumors.

2. The research addresses one of the main societal dangers; rumors, which are related to the most dangerous society group; hypocrites.

3. The research sheds light on the role of the enemies of Islam in targeting the Muslim society from the inside in general and targeting women in specific.

\section{Research Objectives:}

The research has the following objectives:

1. Highlighting the role of Sunnah in diagnosing and solving the society's issues.

2. Revealing the role of hypocrites in spreading rumors.

3. Stressing the dangers of rumors for individuals and the society as a whole.

4. Explaining the fundamentals of addressing and treating rumors.

\section{Research Problem:}

The research tries to answer the following questions:

1. Does the Sunnah address societal issues?

2. What is the role played by hypocrites and the fifth column in spreading rumors?

3. Did the Sunnah texts indicate the dangers of rumors for individuals and the society?

4. Did the Sunnah texts describe the methods of addressing and treating rumors?

\section{Previous Studies:}

1- Hypocrisy and Hypocrites -A Study in the Light of Qur'an and Sunnah- Master thesis by: Anas Mahmoud Ishtewy, University of An-Najah National University, 2016

2- The Incident of the Falsehood as narrated in the Surah An-Nur, and the Role of Hypocrites. A Master thesis by: Abdul Helmy Al-Abdul Latif, Imam Muhammad ibn Saud University, 1983.

3- Rumor in the Light of the Prophetic Sunnah -Objective study- by Hussein bin Ahmed Hamad, 2015. 


\section{Research Methodology and Procedures:}

1. I adopted the selective approach in collecting the Hadiths related to the two rumors spread by hypocrites.

2. I adopted the analytical and deductive approach in understanding the texts and employing them in serving the research topics.

3. I adopted the thematic approach for each Hadith, selecting the paragraphs that are relevant to the research topic and then deploying them to the different sections and topics of the research plan. This was accompanied with introductions and commentaries, where I selected other Hadiths and relied on the explanations of trusted sheikhs to support the research idea.

3. I attributed the Hadiths to their original sources of the Sunnah books, followed by the book, the part, the page, and then the number of the Hadith. For the Hadiths that are not stated in the two Sahihs, I clarified their category based on the judgements of trusted traditional and modern critics and scholars. Translations of the Hadiths were taken from the website Sunnah.com, where you can type parts of the Hadith in Arabic and find the Hadith with its English translation. The translation is adequately accurate and clear.

\section{Research Plan:}

1. Role of hypocrites in spreading rumors in the Prophet's community

1.1 The hypocrites' rumor of the Prophet, peace be upon him, divorcing his wives

1.2 The hypocrites' rumor of the falsehood related to the mother of believers, Aisha

2. Dangers of hypocrites' rumors.

2.1 Honorable Companions fell prey to hypocrites' rumors

2.2 Fast spread of the rumors makes them sound almost true

2.3 Rumors targeting leadership and aiming to weaken it

2.4 Rumors are a slander that causes sleeplessness and crying

2.5 Rumors divide the nation and incite dispute among them

3. Treating and dealing with rumors

3.1 Holding one's tongue from spreading the rumor.

3.2 Asking, enquiring for the truth and referring to the specialized.

3.3 Patience and reliance on Allah until truth is revealed and innocence is proven.

3.4 Forgiveness to erase the traces of the rumor

4. Conclusion 


\section{Role of hypocrites in spreading rumors in the Prophet's community}

Rumor is a dangerous weapon that divides and ruins the society. A rumor is a news item reported without ascertaining the truth. ${ }^{(7)}$ The Prophet's community was targeted by its enemies of polytheists and Jews. However, hypocrites, who lived among Muslims, were even more dangerous. The two topics of this section highlight the role of hypocrites in spreading rumors in two significant incidents: the rumor that the Prophet, peace be upon him, divorced his wives and the rumor of the falsehood related to the mother of believers; Aisha.

\subsection{Hypocrites' rumor that the Prophet peace be upon him divorced his wives}

Divorce ends the relationship between a husband and his wife, breaking the family, which is the nucleus of the society. Abu Musa narrated that Prophet Mohammed peace be upon him said, "If it is morning, Iblis ${ }^{(8)}$ gathers his hosts and says: who led a Muslim astray today I shall dress him with the crown. One [of his hosts] would say: I did not leave him until he divorced his wife." (9)

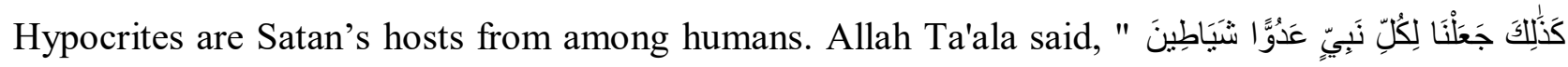
SLikewise did We make for every Messenger an enemy,- evil ones among men and jinns, inspiring each other with flowery discourses by way of deception. If thy Lord had so planned, they would not have done it: so leave them and their inventions alone ${ }^{(10)}$ [Al-An'am:112]. Hypocrites invented a lie against Prophet Mohammed, peace be upon him, and spread the rumor that the Prophet divorced his wives. Al-Bukhari narrated a long Hadith by Omar bin Al-Khattab, where he said, "At that time a talk was circulating among us that (the tribe of) Ghassan were preparing their horses to invade us. My Ansari companion, on the day of his turn, went (to the town) and returned to us at night and knocked at my door violently and asked if I was there. I became horrified and came out to him. He said, Today a great thing has happened.' I asked, 'What is it? Have (the people of) Ghassan come?' He said, 'No, but (What has happened) is greater and more horrifying than that: Allah's Messenge, peace be upon him, has divorced his wives. 'Omar added, "The Prophet, peace be upon him, kept away from his

(1) See: Ibn Mandhur, Lisan Al-Arab Vol. 8/191) and Al-Mu'jam Al-Waseet (503/1)

(2) The word "بلس "إبلس من رحمة الله" is from the root the root may mean: to be silent. The in despair of

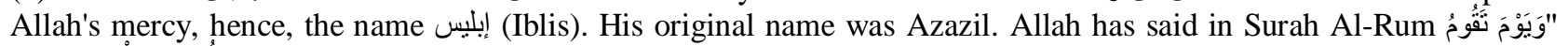
السَّاعَةُ يُبْلِسُ الْمُجْرِمُونَ" (On the Day that the Hour will be established, the guilty will be struck dumb with despair). The name "Iblis" is derived from the root, بلس Iblis is the father of all satans. See: As-Sam'ani, Al-Tafsir, Vol. 3/137; Al-Qurtubi, Al-Tafsir, Vol.1/295

(1) Ibn Habban, Sahih Ibn Habban, Book of History, Chapter on the Beginning of Creation, stating that Iblis puts the crown on the head of the host who caused the gravest affliction (68/14), no.: 6189. Al-Arnaout commented, "Isnad sahih." [Authentic authority]

(2) Yusuf Ali's Translation of the Holy Qur'an

371 IUG Journal of Islamic Studies (Islamic University of Gaza) / CC BY 4.0 
wives and I said "Hafsa is a ruined loser, I had already thought that most probably this (divorce) would happen in the near future... the Hadith. ${ }^{(11) "}$

Ibn Hajar said, "Perhaps the certainty was given to some hypocrites' rumor, which was spread by people. The rumor may have originated because the Prophet, peace be upon him, kept away from his wives. As this was not of the Prophet's habits, they believed that he had divorced his wives." (12) The Ansari found that the Prophet divorcing his wives was greater and more horrifying than the Romans invading the Madinah, and Omar confirmed this notion. This proves that the hypocrites' rumor had a great impact on the Companions and the Prophet's community in whole and that the rumor was more dangerous than the external enemy, although the invasion of the Romans to Madinah was a very significant issue at that time.

\subsection{The hypocrites' rumor of the falsehood related to the mother of believers, Aisha.}

If the rumor that the Prophet, peace be upon him, divorced his wives was greater than the invasion by the Romans, then spreading the falsehood against the Prophet's wife, Aisha the mother of believers, was even more horrifying and lasted for a month. The Prophet, peace be upon him, received no revelation until the rumor had a deep effect on him, his wife Aisha, the family of Abu Bakr and all the Companions.

The slander spread by the hypocrites against the mother of believers, Aisha, is well-known. It is described in the Holy Qur'an and detailed by Aisha in a long Hadith that included, "the one who spread the Ifk (i.e. slander) more, was `Abdullah bin Ubayy Ibn Salul." (Urwa said, "The people propagated the slander and talked about it in his (i.e. 'Abdullah's) presence and he confirmed it and listened to it and asked about it to let it prevail..."(13)

The Hadith is long, and I will cite the remaining parts when detailing the rumor, exposing its dangers and discussing how to treat and deal with it. To avoid repetition, I will cite some of the remaining parts of the Hadith in the following two sections to clarify the dangers of the rumor and the ways of treating it.

\section{Dangers of hypocrites' rumors}

Rumors are a true danger that attacks the society as a whole and spares almost no one. Spreading the slander against the mother of believers, Aisha, was committed by some / few honorable Companions. The rumor spread like wildfire until it resembled an undeniable truth. It targeted the leadership and aimed to weaken it. It deprived the victim of sleep and made her cry. It almost

(3) Al-Bukhari, Sahih Al-Bukhari, the Book of al-Mazalim, higher places of a house, looking upon other houses or not looking upon other houses, whether these places are on roofs or not, (3/133), no.: 2468. The Hadith is long, and I will cite other parts of the Hadith in the topics of the dangers of rumors and addressing the rumor.

(4) Ibn Hajar, Fath Al-Bari, Commentary on the Sahih Al-Bukhari (285/9)

(1) Al-Bukhari, Sahih Al-Bukhari, the Book of Al-Mghazi, the Narration of al-Ifk, (117/5), no.: 4141

372 IUG Journal of Islamic Studies (Islamic University of Gaza) / CC BY 4.0 
brought the Madinah apart and caused dispute between Al-Aus and Al-Khazraj. ${ }^{(14)}$ This section discusses all these points based on the Hadiths narrated by Aisha and Omar regarding the two rumors. The section is divided into five topics.

\subsection{Honorable Companions fell prey to hypocrites' rumors}

One of the main dangers of rumors is that they can be spread by trustworthy people in the society. This gives the rumor a sense of credibility and spreads it even more. This was the case with the Falsehood attributed to the mother of believers, Aisha. Her Hadith also included, "'Urwa also added, "None was mentioned as members of the slanderous group besides ( Abdullah) except Hassan bin Thabit and Mistah bin Uthatha and Hamna bint Jahsh along with others about whom I have no knowledge, but they were a group as Allah said..."

These are honorable Companions; Hassan bin Thabet ${ }^{(15)}$ is the Prophet's poet and defending tongue, Mistah $^{(16)}$ is one of the Muslims who had witnessed the Battle of Badr, and Hamna ${ }^{(17)}$ is the sister of Zeinab bint Jahsh, the mother of believers; may Allah bless them all.

The rumor that the Prophet, peace be upon him, divorced his wife was spoken by the Ansari, Omar's neighbor. He was so sure about the news as if it was certain.

\subsection{Fast spread of the rumors makes them sound almost true}

The danger of the rumor is in how fast it can spread to become the people's main topic for discussion. Aisha said, "After we returned to Medina, I became ill for a month. The people were propagating the forged statements of the slanderers while I was unaware of anything of all that...". Her words "people propagated" indicate how fast the rumor spread like flooding water. Ibn AlAtheer said, "the word (أفاض) indicates that the people rushed into spreading the news". (18) Al Kurani said, "it means that people rushed glibly. The word (ناس) included hypocrites and some Muslims". (19) (إفاضة) indicates rush and means plenty and widespread. It is derived from Allah's

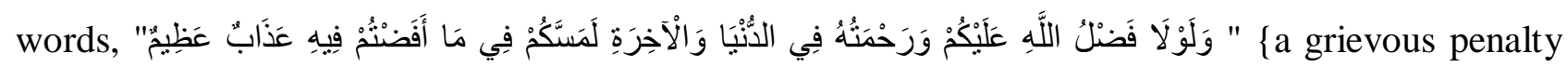
would have seized you in that ye rushed glibly into this affair \} [An-Nur: 14]. ${ }^{(20)}$

(1) Aus and Khazraj are two large Arab tribes attributed to the Azd Tribe, which is one of the greatest Arab tribes that lived in Ma'rib. When the Ma'rib Dam collapsed, they were forced to leave Saba'. Aus and Khazraj moved to Yathreb in Hijaz, and lived there with the Jews for twenty years. There were long wars between the two tribes before Islam. However, they entered Islam and pledged to protect the Prophet (peace be upon him). See: Mu'jam qaba'il al-Arab alqadimah wa-al-hadithah, Vol. 1/17-51.

(2) Ibn Hajar, al-Isaba fi tamyiz al-Sahaba, Vol. 2/55

(3) Ibid. Vol. 6/74

(4) Ibid. Vol. 8/88

$\left({ }^{18}\right)$ Ibn Al-Atheer, Al Nihaya Fi Ghareeb Al Hadith wal Athar (485/3)

(2) Al-Kourani, Al-Kawthar Al-Jari ila Riyad Ahadith Al-Bukhari (275/5)

(3) Al-Ethyoubi, Al-Bahr Al-Muheet Al-Thajjaj fe Sharh Sahih Imam Muslim ibn Al-Hajjaj (127/43)

373 IUG Journal of Islamic Studies (Islamic University of Gaza) / CC BY 4.0 
The mother of believers, Aisha, never expected that anyone would speak ill of her honor, so she went to ask her mother, "...and asked my mother, 'O mother! What are the people talking about?' She said, 'O my daughter! Don't worry, for scarcely is there a charming woman who is loved by her husband and whose husband has other wives besides herself that they (i.e. women) would find faults with her.' I said, 'Subhan-Allah! (I testify the uniqueness of Allah). Are the people really talking in this way?"

Her words, Subhan-Allah! Are the people really talking in this way?" show her surprise and denial. It means that she wondered how such falsehood and slander could happen.

The problem with rumors is that they are so strongly circulated that they begin to sound true. Although there was no revelation for a month, the Prophet, peace be upon him, spoke to Aisha as if the falsehood was true. Aisha narrated, "... While we were in this state, Allah's Messenger, peace be upon him, came, greeted us and sat down. He had never sat with me since that day of the slander. A month had elapsed and no Divine Inspiration came to him about my case. Allah's Apostle then recited Tashah-hud and then said, 'Amma Badu, O 'Aisha! I have been informed such-and-such about you; if you are innocent, then soon Allah will reveal your innocence, and if you have committed a sin, then repent to Allah and ask Him for forgiveness for when a slave confesses his sins and asks Allah for forgiveness, Allah accepts his repentance..."

Even the parents of Aisha dealt with the news as if it were true. She narrated, "...When Allah's Messenger, peace be upon him, finished his speech, my tears ceased flowing completely that I no longer felt a single drop of tear flowing. I said to my father, 'Reply to Allah's Messenger, peace be upon him, on my behalf concerning what he has said.' My father said, 'By Allah, I do not know what to say to Allah's Messenger, peace be upon him. Then I said to my mother, 'Reply to Allah's Messenger, peace be upon him, on my behalf concerning what he has said.' She said, 'By Allah, I do not know what to say to Allah's Messenger, peace be upon him. In spite of the fact that I was a young girl and had a little knowledge of Qur'an, I said, 'By Allah, no doubt I know that you heard this (slanderous) speech so that it has been planted in your hearts (i.e. minds) and you have taken it as a truth. Now if I tell you that I am innocent, you will not believe me, and if I confess to you about it, and Allah knows that I am innocent, you will surely believe me. By Allah, I find no similitude

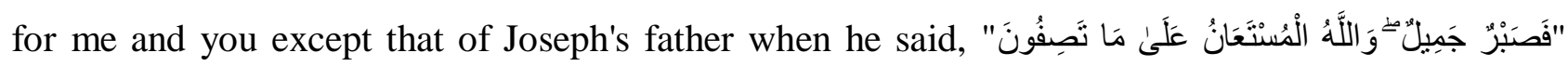
'(For me) patience in the most fitting against that which you assert; it is Allah (Alone) Whose Help can be sought.' [Yousuf: 18]

Aisha's answer to the Prophet's speech, and her parents' abstaining from defending her show the danger of that rumor. It was treated as a fact. This is evident in her words, "... it has been planted in 
your hearts (i.e. minds) and you have taken it as a truth", "you will not believe me", and "and if I confess, you will believe me". If Aisha's close family thought this, what was the case of other people?

\subsection{Rumors targeting and harming the leaders}

Rumors are already considered dangerous for the harm they cause. However, they become even more dangerous when they target the leadership of the community or the head of the state. Both rumors targeted the Prophet, peace be upon him, and his wives. The first rumor was about their divorce and the second, and more dangerous, was about the Prophet's most beloved wife as Narrated Anas [May Allah be pleased with him]:

"It was said: 'O Messenger of Allah! Who is the most beloved of the people to you?' He said: "Aishah.' It was said: 'From the men?' He said: 'Her father ${ }^{(21)}$."'

The Prophet, peace be upon him, described the utmost agony he and his family felt. Narrated Aisha, "So, on that day, Allah's Apostle got up on the pulpit and complained about 'Abdullah bin Ubayy (bin Salul) before his companions, saying, 'O you Muslims! Who will relieve me from that man who has hurt me with his evil statement about my family? By Allah, I know nothing except good about my family and they have blamed a man about whom I know nothing except good and he used never to enter my home except with me.'

\subsection{Rumors are slanders that cause insomnia and crying}

Rumors frame the innocent unjustly and slanderously. During the time of falsehood (ifk), the people spread a stream of invective; Aisha was innocent and said, "Allah knows that I am innocent of it". After her conversation with Um Mistah, Aisha became more ill (she was already ill at the time of falsehood rumor). She said, "When we had finished our affair, Um Mistah and I came back towards my house. Um Mistah stumbled over her robe whereupon she said, "Let Mistah be ruined!" I said to her, "What a bad word you have said! Do you abuse a man who has taken part in the Battle of Badr?' She said, "O you there! Did you not hear what he has said?" I said, "And what did he say?" She then told me the statement of the people of the Ifk (falsehood) which added to my ailment."

As the rumor continued to spread, the pain increased and caused her sleeplessness and made her weep. In the Hadith, she said, "That night I kept on weeping the whole night till the morning. My tears never stopped, nor did I sleep, and morning broke while I was still weeping”.

(1) At-Tirmidhi, Sunan at-Tirmidhi, Book of Virtues, Chapter on the Superiority of Aisha (707/5) no. 3890; he said, "Sahih Hassan" [Authentic authority and Good Hadith].

375 IUG Journal of Islamic Studies (Islamic University of Gaza) / CC BY 4.0 
When the innocent cries or suffers from insomnia, it is not a passing issue. Instead, it continues for days and nights. In the Hadith, she said,

"On that day I kept on weeping so much that neither did my tears stop, nor could I sleep. In the morning my parents were with me, and I had wept for two nights and a day without sleeping and with incessant tears till they thought that my liver would burst with weeping. While they were with me and I was weeping, an Ansari woman asked permission to see me. I admitted her and she sat and started weeping with me".

Regarding the rumor of the Prophet, peace be upon him, divorcing his wives, Omar said, So I dressed myself and offered the Fajr prayer with the Prophet. Then the Prophet entered an upper room and stayed there alone. I went to Hafsa and found her weeping. I asked her, 'Why are you weeping? Did I not warn you? Have Allah's Apostle divorced you all?' She replied, 'I don't know. He is there in the upper room.' I then went out and came to the pulpit and found a group of people around it and some of them were weeping. Then I sat with them for some time".

\subsection{Rumors divide the nation and incite dispute among the people}

The danger of rumors does not affect the falsely accused and their families only. Quite the opposite, it affects the entire society; especially if the person accused is a leader. Then, the society is divided into groups. A group that spreads the rumor intentionally (the hypocrites), a group that falls victim to the rumor and spreads it out of curiosity and lack of self-control, a third group that believes such lies and becomes very intolerant, and others strongly defend the accused. Aisha in the Hadith says, "So Allah's Apostle got up (and addressed) the people and asked for somebody who would take revenge on `Abdullah bin Ubayy bin Salul then. Allah's Apostle, while on the pulpit, said, "O Muslims! Who will help me against a man who has hurt me by slandering my family? By Allah, I know nothing except good about my family, and people have blamed a man of whom I know nothing except good, and he never used to visit my family except with me," Sa`d bin Mu`adh Al-Ansari got up and said, "O Allah's Apostle! By Allah, I will relieve you from him. If he be from the tribe of (Bani) Al-Aus, then I will chop his head off; and if he be from our brethren, the Khazraj, then you give us your order and we will obey it." On that, Sa`d bin 'Ubada got up, and he was the chief of the Khazraj, and before this incident he had been a pious man but he was incited by his zeal for his tribe. He said to Sa`d (bin Mu`adh), "By Allah the Eternal, you have told a lie! You shall not kill him and you will never be able to kill him!" On that, Usaid bin Hudair, the cousin of Sa 'd (bin Mu`adh) got up and said to Sa`d bin 'Ubada, "You are a liar! By Allah the Eternal, we will surely kill him; and you are a hypocrite defending the hypocrites!" So the two tribes of Al-Aus and AlKhazraj got excited till they were on the point of fighting with each other while Allah's Apostle was 
standing on the pulpit. Allah's Apostle continued quietening them till they became silent whereupon he became silent too."

The idea is clear. Fitna would have erupted between the leaders of Al-Aus and Khazraj if it had not been for the Prophet's wisdom, as he suppressed his pain and false statements about his wife and tried to quieten and calm them down.

The above-mentioned five topics and the Hadiths of Aisha and Omar I used as evidence reflect the dangers and horridness of rumors as they inflect severe harm on the accused, i.e. Aisha; the leadership, i.e. the Prophet, peace be upon him; or the great Companions being involved; or the rumor flooding everywhere as though it is an absolute truth. The fitna and dispute almost erupted if it were not for the Prophet's, peace be upon him, wisdom in preventing them.

\section{Treating rumors and dealing with them}

Aisha's and Omar's Hadiths have also reflected the means to treat rumors: People must stop themselves from spreading the rumor, must enquire about details, must be patient, and must be forgiving to erase any traces of the rumors. This section shows the four means to treat rumors.

\subsection{Holding one's tongue from spreading the rumor}

Holding one's tongue from spreading rumors keeps a person safe from doing any act forbidden by Allah. In the Hadith narrated Abu Hurairah, "All things of a Muslim are inviolable for his brother in

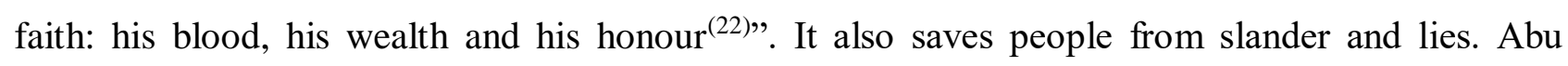
Hurariah narrated, "It is enough falsehood for a man to relate everything he hears ${ }^{(23)),}$

During the time of the rumor of ifk that targeted Aisha, a group of the Companions such as Usama bin Zayd, Ali bin Abi Talib and Barirah mawla Aisha held their tongues and did not spread the rumor. Aisha narrated, “Allah's Apostle called 'Ali bin Abi Talib and Usama bin Zaid when the Divine Inspiration delayed, in order to consult them as to the idea of divorcing his wife. Usama bin Zaid told Allah's Apostle of what he knew about the innocence of his wife and of his affection he kept for her. He said, "O Allah's Apostle! She is your wife, and we do not know anything about her except good." But `Ali bin Abi Talib said, "O Allah's Apostle! Allah does not impose restrictions on you; and there are plenty of women other than her. If you however, ask (her) slave girl, she will tell you the truth." `Aisha added: So Allah's Apostle called for Barira and said, "O Barira! Did you ever see anything which might have aroused your suspicion? (as regards Aisha). Barira said, "By Allah Who has sent you with the truth, I have never seen anything regarding Aisha which I would blame

(1) Muslim, Sahih Muslim, the book of Virtue, Enjoining Good Manners, and Joining of the Ties of Kinship, chapter on the Prohibition of Wronging the Muslim... (1986/4), no. 2564.

(2) Muslim, Sahih Muslim, Introduction, the chapter on the Prohibition of Narrating Everything One Hears (10/1)

377 IUG Journal of Islamic Studies (Islamic University of Gaza) / CC BY 4.0 
her for except that she is a girl of immature age who sometimes sleeps and leaves the dough of her family unprotected so that the domestic goats come and eat it."

The mother of believers Zainab bint Jahsh did not spread the rumor as well and held prevented herself from doing so. Aisha narrated, "Allah's Apostle also asked Zainab bint Jahsh about my case. He said, "O Zainab! What have you seen?" She replied, "O Allah's Apostle! I protect my hearing and my sight (by refraining from telling lies). I know nothing but good (about Aisha)." Of all the wives of Allah's Apostle, it was Zainab who aspired to receive from him the same favor as I used to receive, yet, Allah saved her (from telling lies) because of her piety. But her sister, Hamna, kept on fighting on her behalf so she was destroyed as were those who invented and spread the slander."

\subsection{Asking, enquiring for the truth and referring to the specialized}

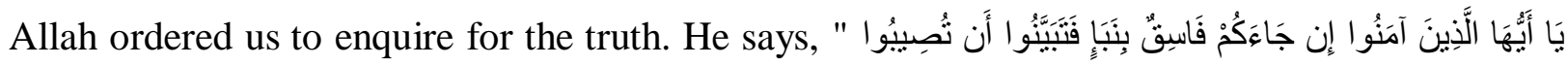

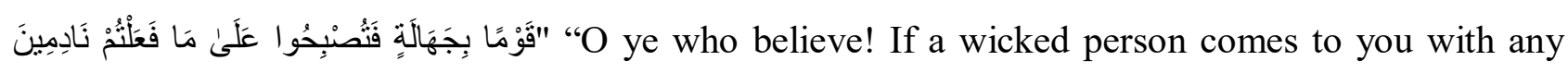
news, ascertain the truth, lest ye harm people unwittingly, and afterwards become full of repentance for what ye have done" [Al-Hujurat:6]. Although this rumor targeted the Prophet, peace be upon him, and his family, he was steadfast and patient so his nation would learn from him the method of enquiry. His questions to Usama bin Zaid, Ali bin abi Talib, Barirah, and Zainab bint Jahsh clearly reflect such method.

After the Prophet, peace be upon him, asked the Companions and enquired for the truth, he asked his wife Aisha despite her bad spiritual state. In the Hadith Aisha said, "While we were in this state, Allah's Messenger, peace be upon him, came, greeted us and sat down. He had never sat with me since that day of the slander. A month had elapsed and no Divine Inspiration came to him about my case. Allah's Apostle then recited Tashah-hud and then said, 'Amma Badu, O `Aisha! I have been informed such-and-such about you; if you are innocent, then soon Allah will reveal your innocence, and if you have committed a sin, then repent to Allah and ask Him for forgiveness for when a slave confesses his sins and asks Allah for forgiveness, Allah accepts his repentance...".

Regarding the rumor of the Prophet, peace be upon him, divorcing his wives, Omar bin AlKhattab went to ask the Prophet, peace be upon him. Omar narrated, "I greeted him and while still standing, I said: "Have you divorced your wives?' He raised his eyes to me and replied in the negative(24)". In another narration, this was added, "I said: Allahu Akbar (25)". In Muslim, Omar

(1) Al-Bukhari, Sahih Al-Bukhari, book of Oppression, chapter on Looking or not looking upon other houses, (133/3), no. 2468. 
narrated, "I stood by the door of the mosque and loudly said, Allah's Apostle did not divorce his

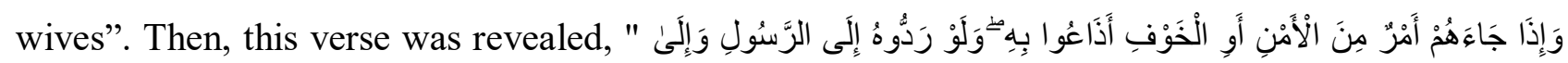

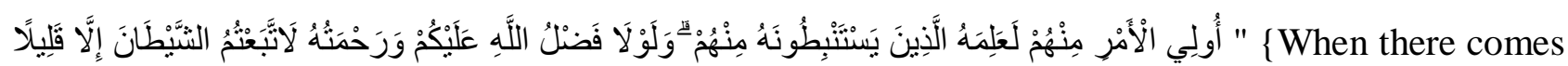
to them some matter touching (Public) safety or fear, they divulge it. If they had only referred it to the Messenger, or to those charged with authority among them, the proper investigators would have tested it from them (direct) $\}$ [An-Nisa: 83$]^{(26)}$.

This verse agreed with Omar, may Allah be pleased with him, on a spectacular way to deal with rumors. The source of the rumor must be questioned and the leadership must be informed about everything. It was of great importance when Omar loudly announced and told the Muslims that the rumor was false. This method must be followed by the ones in charge of Muslims. They must state and declare any false rumors, show the truth and prevent any spread of lies.

\subsection{Patience and reliance on Allah until truth is revealed and innocence is proven}

Clinging to patience during the crisis of the rumor and slander is the best treatment. Patience is always followed by relief. Aisha, may Allah be pleased with her, was very patient and constantly returned to Allah for help. In the Hadith she narrated, "By Allah, I cannot find of you an example except that of Joseph's father: "So (for me) patience is most fitting against that which you assert and it is Allah (Alone) Whose help can be sought. Then I turned away and lay on my bed, and at that time I knew that I was innocent and that Allah would reveal my innocence. But by Allah, I never thought that Allah would sent down about my affair, Divine Inspiration that would be recited (forever), as I considered myself too unworthy to be talked of by Allah with something that was to be recited: but I hoped that Allah's Apostle might have a vision in which Allah would prove my innocence. By Allah, Allah's Apostle had not left his seat and nobody had left the house when the Divine Inspiration came to Allah's Apostle . So there overtook him the same hard condition which used to overtake him (when he was Divinely Inspired) so that the drops of his sweat were running down, like pearls, though it was a (cold) winter day, and that was because of the heaviness of the Statement which was revealed to him. When that state of Allah's Apostle was over, and he was smiling when he was relieved, the first word he said was, "Aisha, Allah has declared your innocence". My mother said to me, "Get up and go to him." I said, "By Allah, I will not go to him

(2) Al-Bukhari, Sahih Al-Bukhari, book of Marriage, Advice to a daughter regarding her husband, (29/7), no. 5191. Muslim, Sahih Muslim, the Book of Divorce, Chapter on Keeping away from one's wives and giving them the choice, (1107/2), no. 1479.

(3) Muslim, Sahih Muslim, the Book of Divorce, Chapter on Keeping away from one's wives and giving them the choice, (1107/2), no. 1479. 


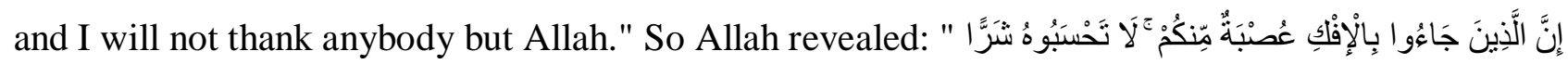

"لَّكُمْ \{ \{Verily! They who spread the Slander are a gang among you. Think it not.... [An-Nur:11]. Allah revealed this to confirm my innocence."

\subsection{Forgiveness to erase the traces of the rumor}

Rumors leave a great scar in the society. The accused never forgets those who have accused $\mathrm{him} / \mathrm{h}$ er and Satan may incite them to retaliate. However, the mother of believers was of great morale as she forgave such doing and prevented those results from happening. In her Hadith, Urwa said, "Aisha disliked to have Hassan ibn Thabit abused in her presence and she used to say, 'It was he who said: My father and his (i.e. my father's) father and my honor are all for the protection of Muhammad's honor from you." In another narration, Urwa said, "I went to Aisha to abuse Hassan; she said, "Do not abuse him. He used to defend Allah's apostle, peace be upon him ${ }^{(27) ",}$

Aisha does resemble her father Abi Bakr, may Allah be pleased with him, as he too forgave Mistah bin Uthatha who dishonored Aisha. In Aisha's Hadith,

Abu Bakr As-Siddiq who used to disburse money for Mistah bin Uthatha because of his relationship to him and his poverty, said, 'By Allah, I will never give to Mistah bin Uthatha

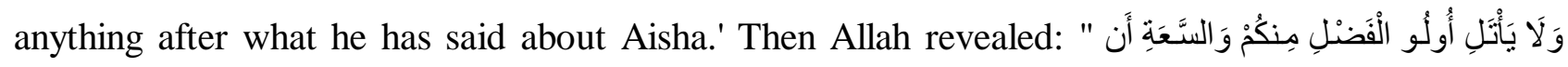

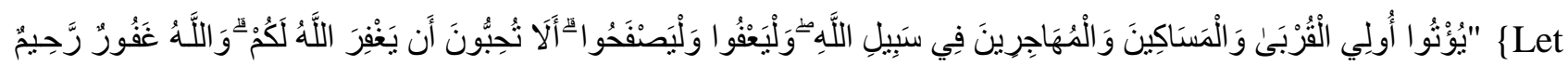
not those among you who are endued with grace and amplitude of means resolve by oath against helping their kinsmen, those in want, and those who have left their homes in Allah's cause: let them forgive and overlook, do you not wish that Allah should forgive you? For Allah is Oft-Forgiving, Most Merciful.\} [An-Nur:22]. Abu Bakr As-Siddiq said, 'Yes, by Allah, I would like that Allah forgive me.' and went on giving Mistah the money he used to give him before. He also added, 'By Allah, I will never deprive him of it at all."

\section{Conclusion}

\subsection{Results}

The following results were drawn from the research:

1- Rumors pose great danger on the people and communities. The planned rumors by hypocrites are considered the most dangerous.

(1) Al-Bukhari, Sahih Al-Bukhari, the Book of Al-Maghazi, the Narration of al-Ifk, (121/5), no. 4145 
2- The two Hadiths of Aisha and Omar highlight the danger of rumors when they target the leadership of the society. Rumors harm the accused, inflict illnesses and insomnia, and make the accused weep. They spread fast that people start receiving them as absolute truths. They incite fitna and division among the people of the society.

3- The two Hadiths of Aisha and Omar explain how to treat and deal with rumors: One must hold their tongue from spreading the rumor; and ask, enquire for the truth and refer to the specialized; be patient and rely on Allah until the truth is revealed and innocence is proven; and forgive to erase the traces of the rumor.

4- The Sunnah diagnoses the ailments of the society and prescribes the optimal treatments.

\subsection{Recommendations}

The researcher recommends the following:

1- Taking care of the Sunnah and its sciences, especially thematic and analytical Hadith which contribute to modern knowledge.

2- Warning against the dangers of rumors and their severe impact on the individual and the society.

3- Fighting rumors and following the methods of the Sunnah in treating them.

4- Warning against the plots of hypocrites and enemies of the nation who are called the fifth column.

\section{References}

The Holy Quran.

Yusuf Ali's translation of the Holy Qur'an. This translation was chosen, as it is, in the translator's opinion, the most eloquent and elaborative.

Sunnah.com for the translations of the Hadiths, as this site was highly recommended by several scholars for its accurate translations.

Bin Hisham, Abdul Malek bin Hisham bin Ayyub al-Himyari al-Mu'afiri, Abu Muhammed, Jamal al-Din (died in 213AH). Reviewed by: Mustafa al-Saqqa and Ibrahim Al-Abyari and Abdul Hafiz Ash-Shalabi, Egypt, Mostafa Bab Halabi \& Sons Press, $2^{\text {nd }}$ ed.

Ibn al-Jawzi, Jamal al-Din Abul Faraj Abdul Rahman bin Ali bin Muhammad al- Jawzi (died in 597AH). Reviewed by: Muhammad Abdul Qader Ata and Mostafa Abdul Qader Ata, Beirut, Dar al-Kotob al-Ilmiyah, $1^{\text {st }}$ ed.

Al-Suhayli, Abu Al-Qasim Abdul Rahman bin Abdullah bin Ahmed al-Suhayli (died in 581AH), Reviewed by: Omar Abdul Salam al-Salami, Beirut, Dar Ihya al-Turath al-Arabi, $1^{\text {st }}$ ed. 
Ibn Al-Atheer, Abu Al-Saadat Al-Mubarak bin Mohammed bin Mohammed, Al-Jazari (1987), Al Nihaya Fi Ghareeb Al Hadith wal Athar, Reviewed by Tahir Ahmed Al Zawi and Mahmoud Mohammed Al-Tahani, Beirut, Al-Maktaba Al-ilmiya.

Ibn Habban, Mohammed bin Habban bin Ahmed Abu Hatim, Al-Tamimi, Al-Busti (1988), Sahih Ibn Habban, Al-Marouf bil Ihsan fi Taqrib Sahih Ibn Habban, Organized by Al-Amir Alaa Eldin Ali bin Balban Al-Farisi, Reviewed by Shuaib Arnaout, Beirut, Al-Risalah Institute, $1^{\text {st }}$ ed.

Ibn Hajar Al-Asqalani, Abu Al-Fadl Ahmed bin Ali bin Mohammed Al-Asqalani (1959), Fath AlBari Sharh Sahih Bukhari, Numbered his books, chapters and Hadiths: Mohammed Foad Abdul-Baqi, Reviewed and supervised by Mohib Al-Din Al-Khatib, Beirut, Dar AlMaarifa.

Ibn Hajar, Abu al-Hassan Ali bin Abu al-Karam Muhammad bin Muhammad bin Abdul Karim bin Abdul Wahid ash-Shaybani al-Jazari, 'Izz al-Din ibn al-Atheer (died in 630AH), Reviewed by: Ali Muhammad Mu'awad and Adel Ahmed Abdul MAwjoud, Beirut, Dar al-Kotob alIlmiyah, $1^{\text {st }}$ ed.

Al-Ethyoubi, Mohammed bin Ali bin Adam bin Mousa (1436 AH), Al-Bahr Al-Muhit Al-thajaj fi Sharh Sahih Muslim bin Al-Hajaj, Riyadh, Dar Ibn Al-Jawzi, $1^{\text {st }}$ ed.

Al-Bukhari, Muhammad bin Ismael. (1422 AH). Al-Jaami' Al-Sahih Al-Musnad Al-Mukhtasar Min Umuri Rasooli-Llahi Wa Sunanihi Wa Ayyaamihi - Sahih Bukhari. Reviewed by: Muhammad Zoheer bin Nasser Al-Nasser, Dar Tawq al-Najat.

At-Tirmidhi, Abu Eissa Muhammad bin Eissa, (1975), Sunan At-Tirmidhi. Reviewed by Ahmed Mohammed Shaker, Egypt, Mustafa Al-Babi Al-Halabi Library, $2^{\text {nd }}$ ed.

Al-Qurtubi, Abu Omar Youssuf bin Abdullah bin Muhammad bin Abdul Barr bin Assem al Namri al-Qurtubi (died in 463AH), Reviewed by: Ibrahim al-Abyari, Beirut, Dar al-Kotob alArabiyya, 1st Ed., 1421AH/2000AD

Al-Kurani, Ahmed bin Ismael bin Othman bin Mohammed Al-Kurani (2008), Al-Kawthar Al-Jari ila Riyad Ahadith Al-Bukhari, Reviewed by Sheikh Ahmed Ezzo Enaya, Beirut, Dar Ihya' Al-Turath Al-Arabi, $1^{\text {st }}$ ed.

Academy of the Arabic Language in Cairo (Ibrahim Mustafa and others), Al-Mu'jam Al-Waseet, Cairo, Dar Al-Dawa.

As-Samani, Abu al-Muthaffar, Mansour bin Abdul Jabbar bin Ahmed al-Marouzi As-Samani alTamimi, Hanafi then Shaf'ii (died in 489AH), Reviewed by: Yasser bin Ibrahim and Ghuneim bin Abbas bin Ghuneim, Riyadh, Dar al-Watan, $1^{\text {st }}$ ed. 
Al-Qurtubi, Abu Abdullah Muhammad bin Ahmed bin Abu Bakr bin Farah al-Ansari of Khazraj, Shams al-Din al-Qurtubi (died in 671 AH), Reviewed by: Ahmed al-Bardouni and Ibrahim Atfish, Cairo, Dar al-Kotob al Misriyya.

Umar Kahhala, Umar bin Rida bin Muhammad Ragheb bin Abdul Ghani Kahhala of Damascus (died in 1408AD), Beirut, Ar-Resalah Publishers, $7^{\text {th }}$ ed.

Muslim bin Hajjaj Al-Qushayri Al-Naysaburi, Sahih Muslim: Al Musnad Al-Sahih Al-Mukhtasar bi Naql Al-Adl an Al-Adl ila Rasool Allah. Reviewed by Muhammad Foad Abdul-Baqi, Beirut, Dar Ihya' Al-Turath Al-Arabi. 